\title{
PŘEVOD STYLU V LITERÁRNÍM PŘEKLADU: VYUŽITÍ PARALELNÍCH KORPUSŮ A DALŠÍCH ELEKTRONICKÝCH NÁSTROJŮ
}

\author{
JITKA ZEHNALOVÁ
}

\begin{abstract}
The contribution deals with the use of electronic tools for investigating the transfer of authorial style in literary translation. It first introduces a method of sentence length analysis of source texts and target texts by means of graphs created by the combined use of the Excel application and of translation memories (TM) created in the CAT tool Memsource Cloud. The applicability of the method is demonstrated on samples of Bohumil Hrabal's texts Cutting It Short and I Served the King of England translated into English by James Naughton and Paul Wilson respectively, and further tested for the purposes of investigating translator's style on other texts by Hrabal (The Little Town Where Time Stood Still and Mr. Kafka and Other Tales from the Times of the Cult) and texts by other Czech authors translated by these translators (Miroslav Holub's text The Jingle Bell Principle and Ivan Klíma's text Waiting for the Dark, Waiting for the Light). Secondly, the quantitative data obtained from TM are summed up in tables and the ways of interpreting it and using it for comparative stylistic analyses are demonstrated. The author comes to the conclusion that the presented methods are useful for exploring translators' style and the transfer of authorial style in translation. Their time-consuming nature is more than balanced off by the quantity and relevance of the obtained results. Their effectiveness can be enhanced by using the TMs as a first step in compiling small-scale corpora, i.e., as files imported into corpus managers, e.g., Sketch Engine, capable of compiling parallel tagged corpora of single texts/ authors/translators and possibly by using the TMs for compiling manual multilevel annotation corpora, e.g., in the Graph Anno tool.
\end{abstract}

Key words: literary translation, Czech authors in English translations, authorial style, translator's style, CAT tools, small-scale corpora

\section{1. Úvod: Jiř́ Levý, elektronické nástroje a paralelní korpusy?}

Zvolené téma se na první pohled může zdát nelogické - co může mít Jiří Levý, který předčasně zemřel v roce 1967, společného s elektronickými nástroji a korpusy? Ovšem styčné body jsou minimálně dva: Zaprvé, Levý byl inovátor a průkopník a v mnoha ohledech vývoj translatologie předznamenal. Ve své práci čerpal z oborů jako kyber- 
netika, teorie her a informatika a dá se předpokládat, že využití moderních technologií v translatologickém výzkumu a hledání nových možností jejich uplatnění by mu bylo blízké. Zadruhé, k Levého klíčovým tématům patří styl a převod stylu v překladu. Jsou to výzkumné oblasti, které jsou v současné mezinárodní translatologii aktuální a které s využitím korpusů těsně souvisí.

Korpusy se v translatologii začaly používat na začátku devadesátých let, za průkopnický je považován článek Mony Baker (1993). Dnes tvoří korpusová studia součást překladatelských studií (Munday 2016). Jak uvádějí Gabriela Saldanha a Sharon O’Brien, včetně odkazů na konkrétní autory a studie, v první vlně výzkumu šlo především o popis toho, jak se překlady liší od nepřeložených textů, v novějším výzkumu pak o daleko širší spektrum výzkumných oblastí, mimo jiné i zkoumání stylu (Saldanha a O’Brien 2014: 56). V korpusových studiích se v naprosté většině jedná o analýzy velkých objemů dat z existujících korpusů, ale Sara Laviosa zmiňuje, že Kirsten Malmkjær navrhuje doplňovat je o „malé a pečlivě vytvořené korpusy“ (Laviosa 1998: 3) a že Munday využívá malého korpusu vytvořeného pro konkrétní výzkum ve své studii překladu jednoho z románů Gabriela Garcíi Márqueze ze španělštiny do angličtiny (Laviosa 1998: 4).

Tato studie patři do oblasti využití malých korpusů vytvořených pro specifické cíle konkrétního výzkumu. Zabýváme se $\mathrm{v}$ ní převodem autorského stylu v literárním překladu a naším cílem je ukázat, že malé korpusy a další elektronické nástroje jsou využitelné pro kvantitativní i kvalitativní stylistické analýzy výchozích textů (VT) a cílových textů (CT). Malými paralelními korpusy míníme korpusy jednotlivých párů VT/CT (př́padně více textů jednoho autora nebo jednoho překladatele), dalšími elektronickými nástroji pak překladové paměti (tj. soubory ve formátu TMX) exportované z některého z nástrojů počítačem podporovaného překladu (CAT nástroje). ${ }^{1}$ Překladové paměti mohou být využity jako předstupeň vytváření malých korpusů např. v korpusovém manažeru Sketch Engine. Jsou však využitelné nejen jako vstupy do korpusových manažerů, ale pro některé typy kvantitativních analýz také samostatně, př́ípadně spolu s aplikací Excel. S využitím malých korpusů a elektronických nástrojů pro daný účel jsou nepochybně spojeny problémy (časová náročnost jejich vytváření, řada metodologických otázek). Užitečnost a efektivnost těchto metod je potřeba ověřit, ale potenciálně nabízejí pro translatologický výzkum nové možnosti.

Studie pojednává o pojetí stylu a převodu autorského stylu u Levého a o pojmech styl překladu a styl překladatele, jak je chápe současný výzkum. Popisujeme v ní využití CAT nástroje Memsource Cloud v kombinaci s aplikací Excel pro analýzu délky vět jako jednoho z rysů autorského stylu a jeho převodu v překladu. Jako příklad používáme Hrabalovy texty Postřžiny a Obsluhoval jsem anglického krále a jejich překlady do angličtiny pořízené Jamesem Naughtonem a Paulem Wilsonem. Dále zkoumáme možnosti této metody pro analýzu stylu překladatele. Pomocí prezentované metody jsou analyzovány další Hrabalovy texty (Městečko, kde se zastavil čas a Inzerát na di̊m, ve kterém už nechci bydlet) a texty dalších českých autorů přeložené uvedenými překladateli (text Miroslava Holuba K principu rolničky přeložený Jamesem Naughtonem a text Ivana Klímy Čekání na tmu, čekání na světlo v překladu Paula Wilsona). V závěru přinášíme návrhy na využití této metody pro různé typy stylistických analýz a dokládáme je na prŕkladech.

1 Zkratka CAT, Computer-Aided Translation, označuje počítačem podporovaný překlad. 


\section{Styl a překlad}

Jiří Levý jako pokračovatel Pražské školy a zastánce funkčního př́stupu k překladu považuje styl za jednu ze základních otázek překladu a stylistické nadání překladatele za prvořadé: „Svůj talent může překladatel uplatnit především při jazykové stylizaci, proto potřebuje v prvé řadě nadání stylistické" (Levý 1998: 68). O významu autorského stylu a jeho převodu v překladu uvažuje ve smyslu „sdělení všech podstatných kvalit originálu čtenáŕi“ (Levý 1998: 89-90). Tato formulace zaměřuje pozornost nejen na „podstatné kvality originálu“, ale také na čtenáře jako na významný parametr překladatelova stylistického rozhodování. Levý také explicitně říká, že „[z]achování stylu je požadavek velmi problematický a v plné míře ne zcela uskutečnitelný “ (Levý 1998: 90), proto má v jeho pojetí převodu autorského stylu zásadní význam pojem hodnota: „Překladatel má zachovat nikoliv formální obrysy textu, nýbrž jejich významovou a estetickou hodnotu, a to prostř̌edky, které mohou [českému] čtenáŕi tyto hodnoty sdělit" (Levý 1998: 90). Pro Levého je styl VT „objektivní fakt, který si překladatel subjektivně přetváŕí (Levý 1998: 91). Do hry o „problematický “ převod autorského stylu tedy kromě čtenáře, pro kterého je překlad určen, vstupuje také překladatel a jeho subjektivní rozhodování - důraz na čtenáře a na překladatele (který počítá s perspektivou čtenáře) je charakteristický pro celé Levého dílo.

V české translatologii zakotvené v Pražské škole je styl samozřejmou a významnou součástí úvah o překladu, ale v mezinárodním kontextu se slovo styl v odborné literatuře až na výjimky dlouho objevovalo jen okrajově, pokud vůbec (Snell-Hornby 1988: 119-121). Ke změně došlo $\mathrm{v}$ devadesátých letech se vznikem výše zmiňovaných korpusových překladatelských studií, která kromě překladových univerzálií zaměřila pozornost také na styl překladatele. Po roce 2000 byla publikována řada stylistických studií (např. Baker 2000; Malmkjær 2003; Boase-Beier 2006; Bosseaux 2007; Kenny 2001; Saldanha 2011), které ovšem styl překladatele chápou různě. Tyto odlišné př́stupy rozebírá Gabriela Saldanha a uvádí, že Kirsten Malmkjær (2003) a Jean Boase-Beier (2006) chápou styl překladatele jako „způsob reagování na VT“, zatímco Mona Baker (2000) jako „idiosynkratický styl, který se nemění u několika CT navzdory rozdílům mezi VT“ (Saldanha 2011: 27). Domníváme se, že oba př́stupy mají své opodstatnění a že předkládaná metoda zkoumání délky vět je efektivně využitelná jak pro analyzování „způsobu reagování na VT“, tak pro odhalování „otisku palce“, jak idiosynkratický styl překladatele metaforicky označuje Mona Baker (2000: 245).

\section{Možnosti využití CAT nástroje Memsource Cloud pro analýzu délky vět ve $\mathrm{VT}$ a $\mathrm{CT}$}

Pomocí nástroje Memsource Cloud zkoumáme převod jednoho ze specifických rysů Hrabalova stylu - orálního proudu, konkrétně délky vět - $\mathrm{z}$ češtiny do angličtiny dvěma překladateli. Analyzovanými texty jsou Postřižiny (1970/1976), v překladu Jamese Naughtona jako Cutting It Short (1993), a Obsluhoval jsem anglického krále (1971), v překladu Paula Wilsona jako I Served the King of England (2007). Skutečnosti, že převod daného rysu Hrabalova autorského stylu se u těchto dvou překladatelů značně liší, jsme si byli předem vědomi: 
„James NAUGHTON je jediný z Hrabalových překladatelů, který přesně reprodukuje jeho typický styl: Heim, Wilson a Pargeterová zasahují do členění textu a podstatně mění texturu Hrabalovy prózy. [...] Wilson [...] (možná na podnět nakladatele) [...] vnucuje románu Obsluhoval jsem anglického krále styl poněkud odlišný, než v jakém byl napsán [...] K nejzávažnějším strukturním změnám patří jako obvykle rozčlenění volně plynoucí prózy do normálních odstavců a místy dost drastické přerušování plynoucí věty." (Partridge 2000: $668-9)^{2}$

Naším cílem bylo vytvořit metodu, která by umožnila tyto rozdíly kvantifikovat, vyjádřit vizuálně a následně interpretovat. Dalším cílem bylo ověřit, zda je efektivní a využitelná jako jedna $\mathrm{z}$ metod zkoumání převodu stylu v překladu.

Metodologie vytváření níže uvedených a komentovaných grafů byla podrobně popsána jinde (Zehnalová 2016), proto zde uvádíme jen stručný popis: Kvalitní scan VT byl po editaci a převedení na formát DOCX nebo RTF vložen do nástroje Memsource Cloud (MSC), který provedl automatickou segmentaci. Ta byla zkontrolována a př́padně manuálně upravena. Stejně jsme postupovali u CT, s tím rozdílem, že jednotlivé segmenty bylo nutné vkládat manuálně. Výstupy z MSC udávají Tabulka 1 a Tabulka 2:

Tabulka 1: Výstupy z MSC za texty Postřižiny / Cutting It Short

\begin{tabular}{|l|c|c|}
\hline \multicolumn{1}{|c|}{ Výstupy z MSC } & $\begin{array}{c}\text { VT: } \\
\text { Postřižiny }\end{array}$ & $\begin{array}{c}\text { CT: } \\
\text { Cutting It Short }\end{array}$ \\
\hline Délka textu (počet slov) & 29799 & 38235 \\
\hline Délka textu (počet znaků) & 140920 & 167857 \\
\hline Délka textu (počet segmentů) & 847 & 862 \\
\hline Průměrná délka segmentu (počet znaků) & 166 & 195 \\
\hline Tři nejdelší segmenty (počet znaků) & 3647 & 1814 \\
& 3511 & 1639 \\
& 3459 & 1602 \\
\hline
\end{tabular}

Data za Postřižiny / Cutting It Short ukazují, že:

- překladatel zasahoval do délky vět (segmentů);

- v některých případech značně (viz délka tří nejdelších segmentů);

- celkově nebyly posuny tak výrazné, jak naznačuje srovnání tří nejdelších segmentů: počet segmentů CT je jen mírně vyšší než počet segmentů VT a průměrná délka segmentu je dokonce vyšší u CT než u VT.

2 James NAUGHTON is the only one of Hrabal's translators who exactly reproduces this typical manner: Heim, Wilson and Pargeter all break up their respective texts, significantly altering the texture of Hrabal's prose. [...] Wilson [...] (perhaps with his publisher's encouragement) [...] appears to have ended up imposing on the novel I Served the King of England a style slightly different from that in which it was written [...] As usual the most serious structural change is the breaking up of the free-flowing prose into normal paragraphs and the forcing of sometimes quite drastic breaks in the sentence flow. (Překlad autorka studie). 
Tabulka 2: Výstupy z MSC za vzorky textů Obsluhoval jsem anglického krále / I Served the King of England (kapitoly „Sklenice grenadýny“ / „A Glass of Grenadine“, „Hotel Tichota“ / „Hotel Tichota“ a „Obsluhoval jsem anglického krále“ / „I Served the King of England“)

\begin{tabular}{|l|c|c|}
\hline \multicolumn{1}{|c|}{ Výstupy z MSC } & $\begin{array}{c}\text { VT: } \\
\text { Obsluhoval jsem } \\
\text { anglického } \text { krále }\end{array}$ & $\begin{array}{c}\text { CT: } \\
\text { I Served the King } \\
\text { of England }\end{array}$ \\
\hline Délka textového vzorku (počet slov) & 36573 & 41366 \\
\hline Délka textového vzorku (počet znaků) & 166500 & 177733 \\
\hline Délka textového vzorku (počet segmentů) & 360 & 1138 \\
\hline Průměrná délka segmentu (počet znaků) & 463 & 156 \\
\hline Tři nejdelší segmenty (počet znaků) & 6559 & 905 \\
& 5061 & 696 \\
& 3428 & 683 \\
\hline
\end{tabular}

Data za tři kapitoly textů Obsluhoval jsem anglického krále / I Served the King of England ukazují, že:

- zásahy překladatele do délky vět byly extrémní;

- počet segmentů je více než třikrát vyšší v CT než ve VT;

- průměrná délka segmentu je téměř třikrát vyšší ve VT než v CT;

- počty znaků ve třech nejdelších segmentech ukazují ještě větší disproporce.

Údaje z MSC (počty znaků za každý segment) jsme následně vložili do tabulek aplikace Excel. Výstupem z Excelu jsou grafy, které znázorňují výsledky analýzy vizuálně. K dispozici máme grafy za jednotlivé kapitoly celého VT a CT Postřižin a za tři kapitoly Anglického krále. Pro vysvětlení použité metody postačí uvést jeden graf za Postřižiny a jeden za Anglického krále.

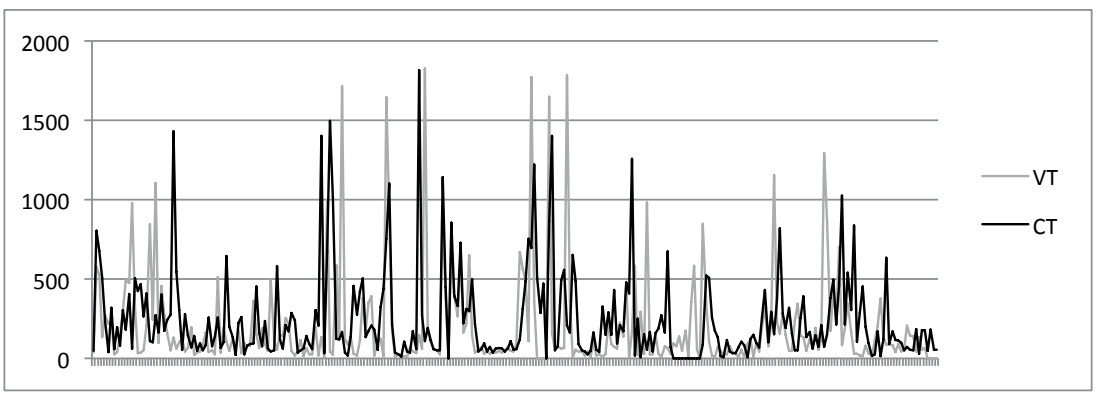

Graf 1: Délka segmentů ve VT a CT: Postřižiny / Cutting It Short (kapitoly 9-12)

Pozn. vertikální osa $=$ počet znaků $\mathrm{v}$ segmentu; horizontální osa $=$ počet segmentů $\mathrm{v}$ daném textovém vzorku; barvy: šedá $=$ VT, černá $=$ CT

Graf (1) za Postřižiny / Cutting It Short názorně ukazuje, že překladatel (James Naughton) převedl délku vět (segmentů) VT relativně velmi přesně. Délku vět zjevně považoval za jednu z podstatných kvalit originálu, jehož významovou a estetickou hodnotu je cílový čtenář schopen ocenit. Graf (2) za kapitolu Obsluhoval jsem anglického krále / I Served the 


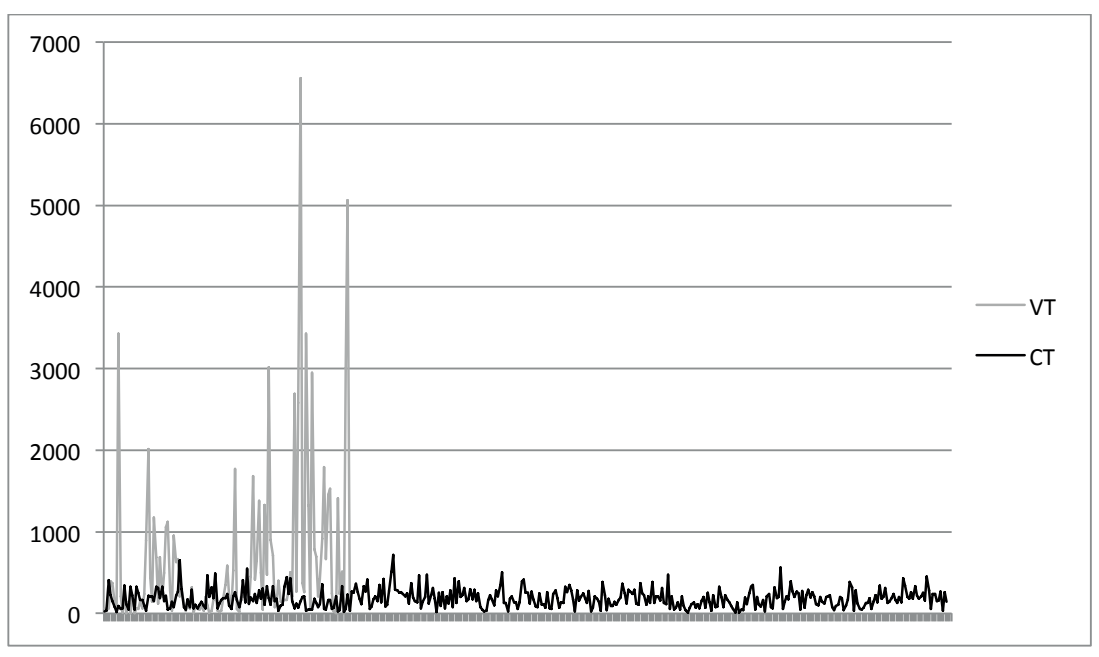

Graf 2: Délka segmentů ve VT a CT: Obsluhoval jsem anglického krále / I Served the King of England (kapitola „Obsluhoval jsem anglického krále“ / „I Served the King of England“)

Pozn . vertikální osa $=$ počet znaků $\mathrm{v}$ segmentu; horizontální osa $=$ počet segmentů $\mathrm{v}$ daném textovém vzorku; barvy: šedá $=\mathrm{VT}$, černá $=\mathrm{CT}$

King of England ukazuje, že zásahy překladatele (Paul Wilson) do délky vět byly razantní, že nivelizují tento rys Hrabalova autorského stylu a srovnání s grafy za další kapitoly, které zde neuvádíme, dokládá, že jsou nejrazantnější právě v kapitole „Obsluhoval jsem anglického krále“ / „I Served the King of England“, kde je tento rys autorského stylu ve VT nejvýraznější. Překladatel se patrně domníval, že tuto významovou a estetickou hodnotu by cílový čtenář neocenil, př́ípadně že by ztěžovala recepci textu. Grafy názorně ukazují

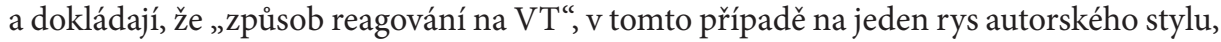
se u jednotlivých překladatelů může zásadně lišit.

V těchto souvislostech se nabízejí dvě výzkumné otázky:

1) Patří relativně velmi přesné (relativně ve srovnání s Wilsonovým překladem) převádění délky vět $\mathrm{v}$ překladu Jamese Naughtona a razantní zásahy do délky vět $\mathrm{v}$ překladu Paula Wilsona ke způsobu reagování těchto překladatelů i na další Hrabalovy texty?

2) Pokud ano, jsou tyto způsoby součástí jejich idiosynkratického stylu? Pokud ne, dají se u těchto překladatelů vystopovat nějaké tendence ve způsobu převodu délky vět?

Pro zodpovězení těchto otázek jsme použili stejnou metodu. Grafy (3) a (4) ukazují, jakým způsobem přistoupili tito překladatelé $\mathrm{k}$ převodu délky vět $\mathrm{u}$ Hrabalových textů Městečko, kde se zastavil čas (1991) v překladu Jamese Naughtona The Little Town Where Time Stood Still (1993/1994) a Inzerát na di̊m, kde už nechci bydlet $(1965 / 2003)$ v překladu Paula Wilsona Mr. Kafka and Other Tales from the Times of the Cult (2015). Grafy (9) a (10) znázorňují převod délky vět použitý Jamesem Naughtonem u textu Miroslava Holuba K principu rolničky (1987) v překladu The Jingle Bell Principle (1992) a Paulem Wilsonem u textu Ivany Klímy Čekání na tmu, čekání na světlo (1993/1996) v překladu Waiting for the Dark, Waiting for the Light (1994/1995). 


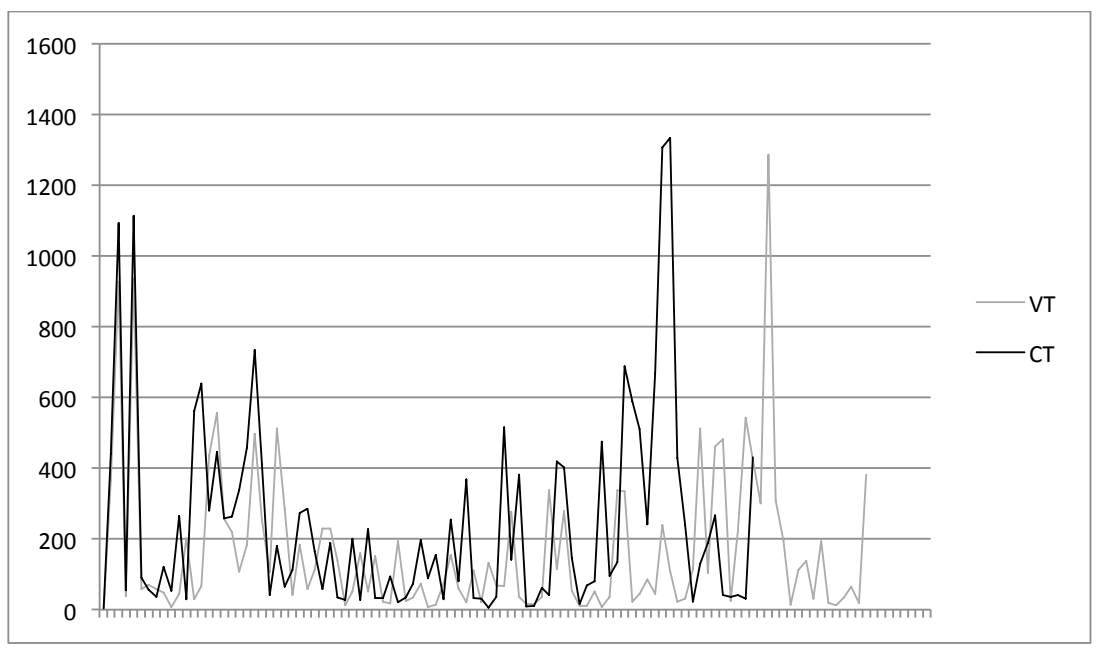

Graf 3: Délka segmentů ve VT a CT: Městečko, kde se zastavil čas / The Little Town Where Time Stood Still (kapitola „1“/ „One“)

Pozn vertikální osa $=$ počet znaků $\mathrm{v}$ segmentu; horizontální osa $=$ počet segmentů $\mathrm{v}$ daném textovém vzorku; barvy: šedá $=$ VT, černá $=\mathrm{CT}$

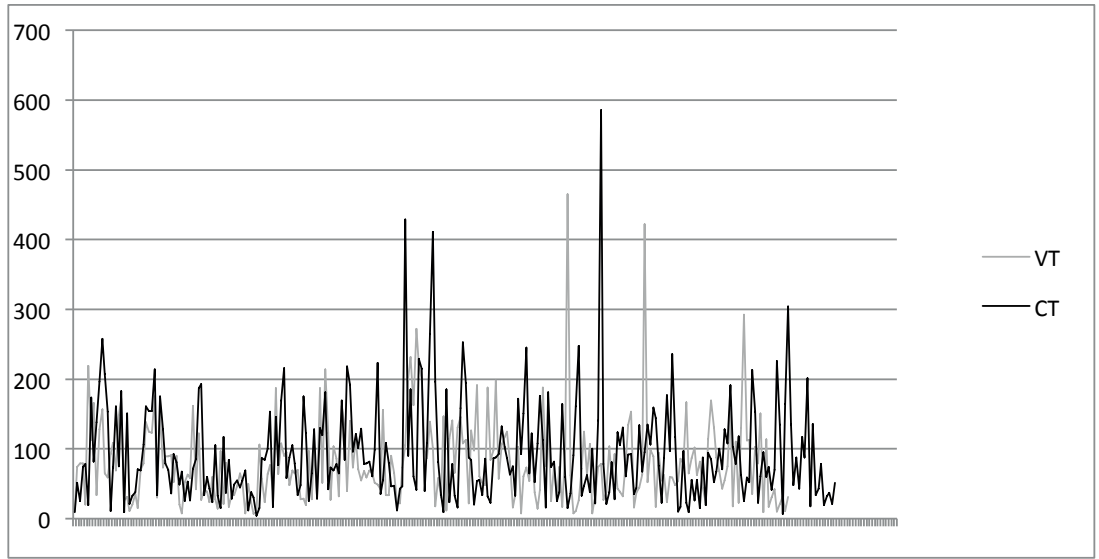

Graf 4: Délka segmentů ve VT a CT: Inzerát na di̊m, kde už nechci bydlet / Mr. Kafka and Other Tales from the Times of the Cult (povídka „-kafkárna“3 / „Mr. Kafka“)

Pozn vertikální osa $=$ počet znaků $\mathrm{v}$ segmentu; horizontální osa $=$ počet segmentů $\mathrm{v}$ daném textovém vzorku; barvy: šedá $=$ VT, černá $=$ CT

3 V analyzovaném vydání má název povídky uvedenou podobu. 
Z grafů (3) a (4) je zřejmé, že odpověd’ na první otázku je záporná. Relativně velmi přesné převádění délky vět $\mathrm{u}$ Jamese Naughtona a razantní zásahy do délky vět $\mathrm{u}$ Paula Wilsona nepatří ke způsobu reagování těchto překladatelů i na jiné Hrabalovy texty. Naughtonovy zásahy do délky vět jsou větší, než tomu bylo v předchozím překladu, jeho strategie spočívá v častém prodlužování segmentů CT, čímž dochází dokonce k poměrně významné změně počtu segmentů (CT 88 / VT 103 segmentů, tedy pomèr CT/VT 0,85), což se v grafu jeví jako „zkráceni“ CT. Ještě daleko zásadnější a při srovnání grafů viditelnější je změna Wilsonovy strategie převodu délky vět. Strategie je relativně (v porovnání s Anglickým králem) velmi přesná, spočivá ve zkracování i prodlužování segmentů, takže výsledkem je zvýšení počtu segmentů CT (CT 278 / VT 261 segmentů, tj. poměr CT/ VT 1,07). Z hlediska převodu délky vět (segmentů) je tedy Wilsonův překlad Kafkárny přesnější než Naughtonův překlad první kapitoly Městečka.

Grafy (5) a (6) ukazují, že strategie obou překladatelů spočívá v kombinaci zkracování a prodlužování segmentů s výsledným zvýšením počtu segmentů v CT. Holubův text přeložený Jamesem Naughtonem charakterizují tyto údaje: CT 181 a VT 170 segmentů, tj. poměr CT/VT 1,06), Klímův text přeložený Paulem Wilsonem tyto údaje: CT $170 \mathrm{a}$ VT 150 segmentů, tj. poměr CT/VT 1,13). Pokud jde o druhou otázku, týkající se idiosynkratického stylu překladatele, byla částečně zodpovězena už výše. Relativně přesný převod délky vět u Jamese Naughtona a razantní zkracování vět u Paula Wilsona není způsobem, kterým tito překladatelé reagují na všechny Hrabalovy texty, není tudíž součástí jejich idiosynkratického překladatelského stylu. Údaje za další překlady to potvrzují.

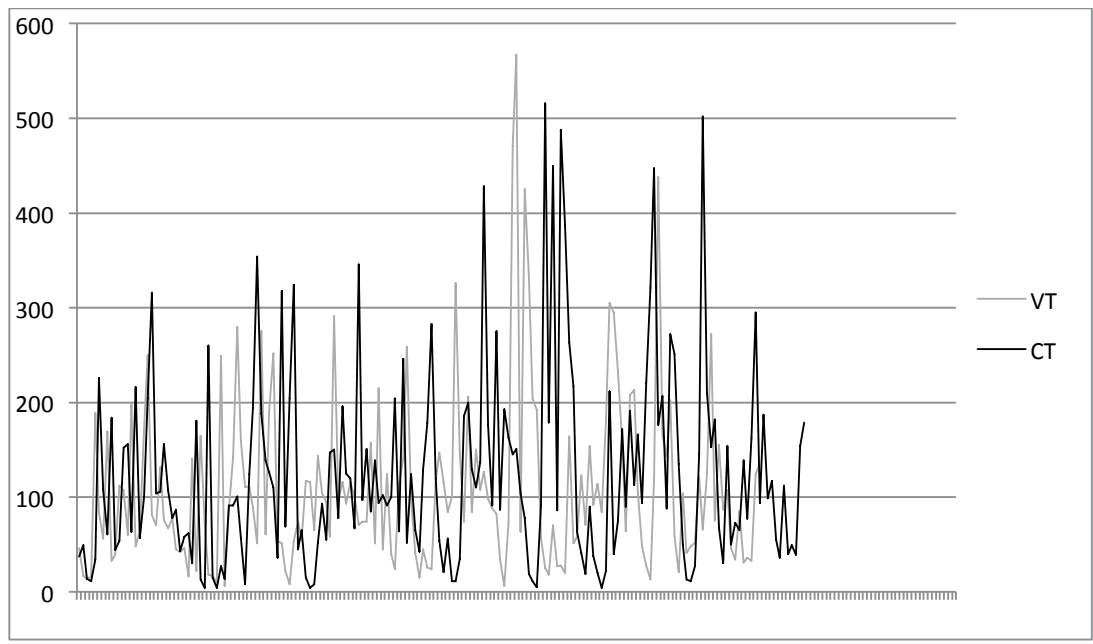

Graf 5: Délka segmentů ve VT a CT: K principu rolničky / The Jingle Bell Principle (sloupky „Pravidla sloupkü“, „, , brana automobilu“, „Cestičky“, „Vratká regulérnost světa“, „,Mouchy“, „, zavazadle nedílném“, „Naučná brašna“ / „The Rules of Writing Short Columns“, „In Defence of the Motor-Car“, „Pathways“, „The Fragile Regularity of the World“, „Flies“, „On Inseparable Baggage“, „The Instructive Camera-Case“) Pozn. vertikální osa $=$ počet znaků $\mathrm{v}$ segmentu; horizontální osa $=$ počet segmentů $\mathrm{v}$ daném textovém vzorku; barvy: šedá $=$ VT, černá $=$ CT 


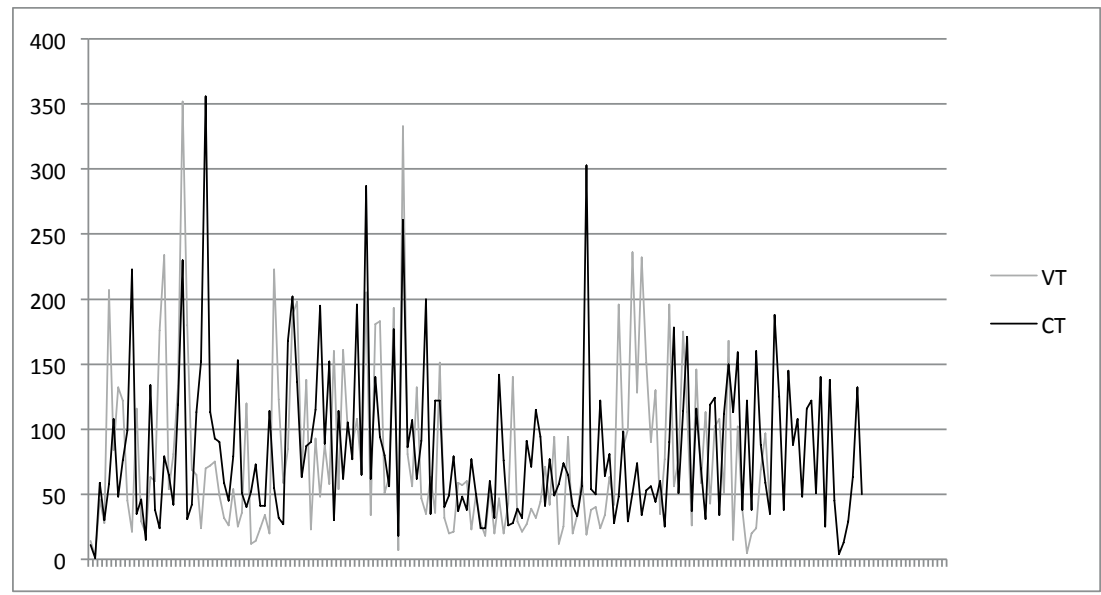

Graf 6: Délka segmentů ve VT a CT: Čekání na tmu, čekání na světlo / Waiting for the Dark, Waiting for the Light („Kapitola první, 1.“ / „Chapter One, 1“)

Pozn. vertikální osa $=$ počet znaků $\mathrm{v}$ segmentu; horizontální osa $=$ počet segmentů $\mathrm{v}$ daném textovém vzorku; barvy: šedá $=$ VT, černá $=$ CT

Tabulka 3: Údaje za analyzované překlady Jamese Naughtona

\begin{tabular}{|c|c|c|c|c|c|c|}
\hline \multicolumn{7}{|c|}{ James Naughton } \\
\hline \multirow[t]{2}{*}{ Autor } & \multirow[t]{2}{*}{ Text / Poměr VT/CT } & \multirow[t]{2}{*}{ Vzorek } & \multicolumn{3}{|c|}{ Délka vzorku } & \multirow{2}{*}{$\begin{array}{l}\text { Zásahy do délky } \\
\text { segmentu }\end{array}$} \\
\hline & & & znaky & slova & segm. & \\
\hline \multirow{4}{*}{$\begin{array}{l}\text { Bohumil } \\
\text { Hrabal }\end{array}$} & $\begin{array}{l}\text { Postřižiny } \\
\text { Cutting It Short }\end{array}$ & $\begin{array}{l}\text { celý text } \\
\text { celý text }\end{array}$ & $\begin{array}{l}140920 \\
167857\end{array}$ & $\begin{array}{l}29799 \\
38235\end{array}$ & $\begin{array}{l}847 \\
862\end{array}$ & \\
\hline & \multicolumn{2}{|l|}{ Poměr CT/VT } & 1,19 & 1,28 & 1,018 & minimální \\
\hline & $\begin{array}{l}\text { Městečko } \\
\text { Little Town }\end{array}$ & "1" & $\begin{array}{l}14327 \\
17333\end{array}$ & $\begin{array}{l}3121 \\
4147\end{array}$ & $\begin{array}{l}103 \\
88\end{array}$ & \\
\hline & \multicolumn{2}{|l|}{ Poměr CT/VT } & 1,21 & 1,33 & 0,85 & střední \\
\hline \multirow{2}{*}{$\begin{array}{l}\text { Miroslav } \\
\text { Holub }\end{array}$} & $\begin{array}{l}\text { K principu rol. } \\
\text { Jingle Bell Pr. }\end{array}$ & $\begin{array}{l}7 \text { sloupků } \\
7 \text { sloupků }\end{array}$ & $\begin{array}{l}15937 \\
18916\end{array}$ & $\begin{array}{l}2880 \\
3850\end{array}$ & $\begin{array}{l}170 \\
181\end{array}$ & \\
\hline & \multicolumn{2}{|l|}{ Poměr CT/VT } & 1,19 & 1,34 & 1,06 & malé \\
\hline
\end{tabular}

Na druhou část dotazu (zda se dají ve způsobu převodu délky vět vystopovat u těchto překladatelů nějaké tendence) je odpověd' kladná, viz Tabulku 3 a 4 . Zásahy do délky vět

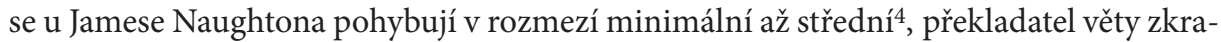
cuje i prodlužuje, v jednom prrípadě dochází ke snížení počtu vět v CT. U Paula Wilsona se zásahy do délky vět pohybují od malých přes střední až po extrémní, překladatel věty zkracuje i prodlužuje, ve všech případech dochází ke zvyšování počtu vět v CT. Až další výzkum by prokázal, zda tyto tendence platí i pro další překlady těchto překladatelů.

4 Na stupnici: Do $2 \%$ minimální, 3-10 \% malé, 11-50 \% střední, 51-100 \% velké, více než 100 \% extrémní. 
Tabulka 4: Údaje za analyzované překlady Paula Wilsona

\begin{tabular}{|c|c|c|c|c|c|c|}
\hline \multicolumn{7}{|c|}{ Paul Wilson } \\
\hline \multirow[t]{2}{*}{ Autor } & \multirow{2}{*}{$\begin{array}{l}\text { Text / Poměr VT/ } \\
\text { CT }\end{array}$} & \multirow[t]{2}{*}{ Vzorek } & \multicolumn{3}{|c|}{ Délka vzorku } & \multirow{2}{*}{$\begin{array}{l}\text { Zásahy do délky } \\
\text { segmentu }\end{array}$} \\
\hline & & & znaky & slova & segm. & \\
\hline \multirow{4}{*}{$\begin{array}{l}\text { Bohumil } \\
\text { Hrabal }\end{array}$} & $\begin{array}{l}\text { Anglický král } \\
\text { King of Engl. }\end{array}$ & $\begin{array}{l}3 \text { kapitoly } \\
3 \text { kapitoly }\end{array}$ & $\begin{array}{l}166500 \\
177733\end{array}$ & $\begin{array}{l}36573 \\
41366\end{array}$ & $\begin{array}{l}360 \\
1138\end{array}$ & \\
\hline & \multicolumn{2}{|l|}{ Poměr CT/VT } & 1,07 & 1,13 & 3,16 & extrémní \\
\hline & $\begin{array}{l}\text { Inzerát na dům } \\
\text { Mr. Kafka and }\end{array}$ & $\begin{array}{l}\text { „-kafkárna“" } \\
\text { „Mr. Kafka“ }\end{array}$ & $\begin{array}{l}17573 \\
21313\end{array}$ & $\begin{array}{l}3571 \\
4797\end{array}$ & $\begin{array}{l}260 \\
277\end{array}$ & \\
\hline & \multicolumn{2}{|l|}{ Poměr CT/VT } & 1,21 & 1,34 & 1,07 & malé \\
\hline \multirow{2}{*}{$\begin{array}{l}\text { Ivan } \\
\text { Klíma }\end{array}$} & $\begin{array}{l}\text { Čekání } \\
\text { Waiting }\end{array}$ & $\begin{array}{l}\text { „K. první, } 1 \text { “" } \\
\text { „Ch. One, 1“ }\end{array}$ & $\begin{array}{l}10072 \\
11606\end{array}$ & $\begin{array}{l}1980 \\
2545\end{array}$ & $\begin{array}{l}149 \\
169\end{array}$ & \\
\hline & \multicolumn{2}{|l|}{ Poměr CT/VT } & 1,15 & 1,29 & 1,13 & střední \\
\hline
\end{tabular}

Použitá metoda (grafické znázornění, kvantitativní vyhodnocení a interpretace dat) analýzy zásahů překladatele do délky vět se tedy dá využít pro srovnávání více překladů a/ nebo více překladatelů. Další možností je použít ji pro podrobnější analýzy jednotlivých překladů, a to bud' samostatně, nebo v kombinaci s kvalitativní analýzou (např. v jakých částech textu dochází ke zkracování/prodlužování vět - v pásmu vypravěče, v dialozích postav apod. a s jakými důsledky pro charakterizaci postav, prostředí apod.), případně v kombinaci s analýzou dalších stylistických rysů. Následující rozbor je ukázkou toho, jak se kvantitativní data a grafické znázornění dají uplatnit pro detailnější analýzu jednoho překladu.

Analyzovaným textem je vzorek z textu Ivany Klímy Čekání na tmu, čekání na světlo v překladu Paula Wilsona Waiting for the Dark, Waiting for the Light. Následující grafy (7) a (8) se od grafư (9) a (10) liší způsobem zobrazení, v obou případech však jde o znázornění toho, jak jsou délky vět rozloženy v textu ukázky, a to samostatně za VT a CT: VT se skládá z menšího počtu segmentů, které se od sebe relativně výrazně liší svou délkou, CT se skládá $z$ většího počtu segmentů s méně výraznými rozdíly v délce segmentů.

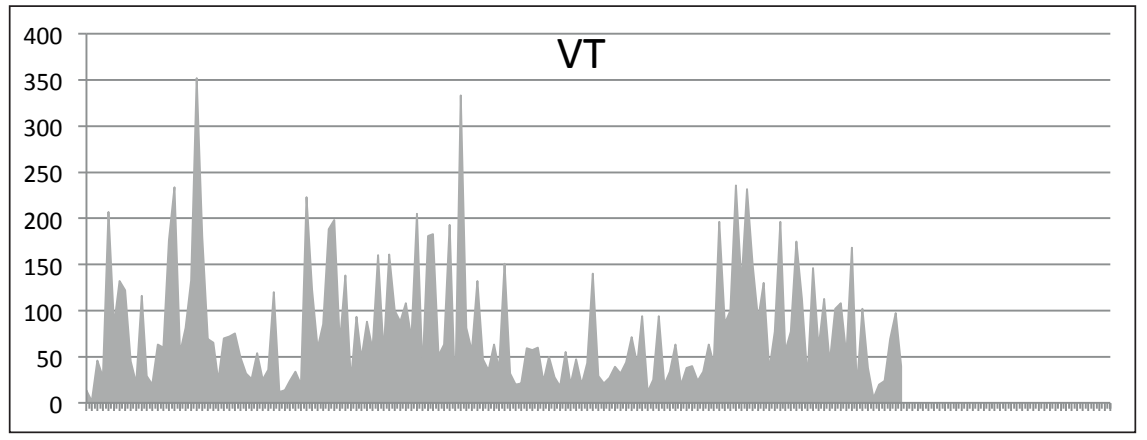

Graf 7: Délka a počet segmentů VT: Čekání na tmu, čekání na světlo („Kapitola první, 1.“)

Pozn. vertikální osa $=$ počet znaků $\mathrm{v}$ segmentu; horizontální osa $=$ počet segmentů $\mathrm{v}$ daném textovém vzorku; barvy: šedá $=\mathrm{VT}$ 
Podrobnější zobrazení v grafech (9) a (10) lépe vyjadřuje celkovou strategii převodu délky vět. Délka nejdelších segmentů je rozložena rovnoměrněji, takže rozdíly mezi nejdelšími segmenty jsou menší než ve VT, větší počet segmentů je ve stř̌ední části spektra (31 až 200 znaků), hlavní změnou je prodlužování nejkratších segmentů (výrazně menší počet segmentů má méně než 30 znaků). Celkově se překladatelská strategie dá popsat jako nivelizace rozdílů $\mathrm{v}$ délce vět.

Tabulka 5 podává informace, které jsou v Grafech 9 a 10 zachyceny vizuálně, pomocí absolutních čísel a procentuálních poměrů. Procento nejdelších segmentů se příliš neliší, ale rozložení jejich délky je rovnoměrnější v CT, procento nejkratších segmentů je výrazně vyšší ve VT, procento středně dlouhých segmentů je vyšší v CT.

Data prezentovaná v grafech a tabulkách dokládají, že změny délek vět, ke kterým $v$ překladu došlo, nebyly náhodné.

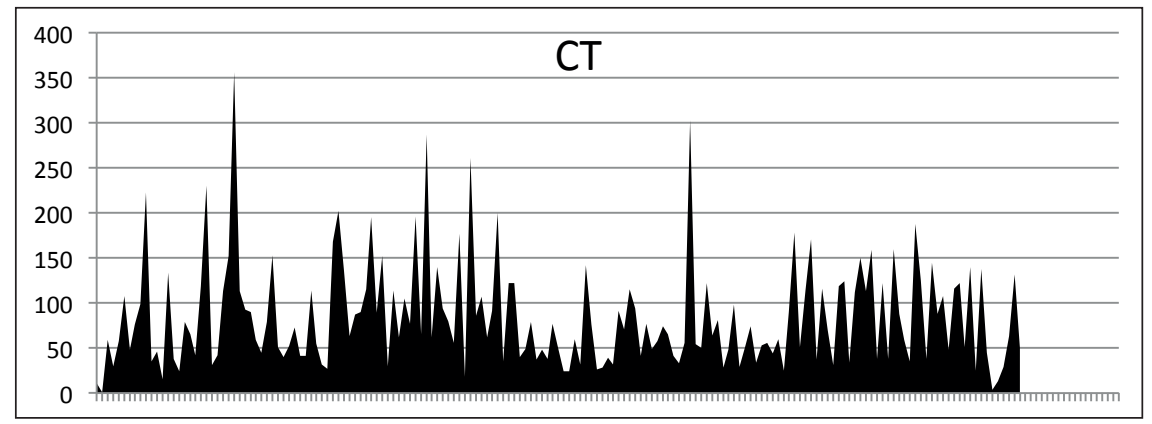

Graf 8: Délka a počet segmentů CT: Waiting for the Dark, Waiting for the Light („Chapter One, 1“) Pozn. vertikální osa $=$ počet znaků v segmentu; horizontální osa $=$ počet segmentů v daném textovém vzorku; barvy: černá $=\mathrm{CT}$

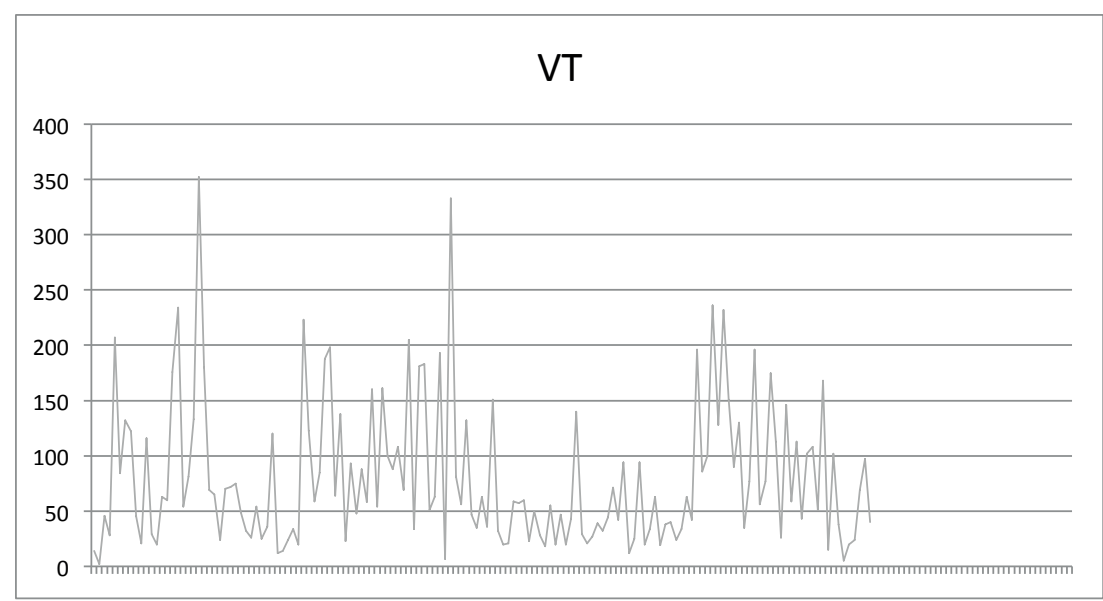

Graf 9: Délka a počet segmentů VT: Čekání na tmu, čekání na světlo („Kapitola první, 1.“)

Pozn. vertikální osa $=$ počet znaků v segmentu; horizontální osa = počet segmentů v daném textovém vzorku; barvy: šedá $=$ VT 


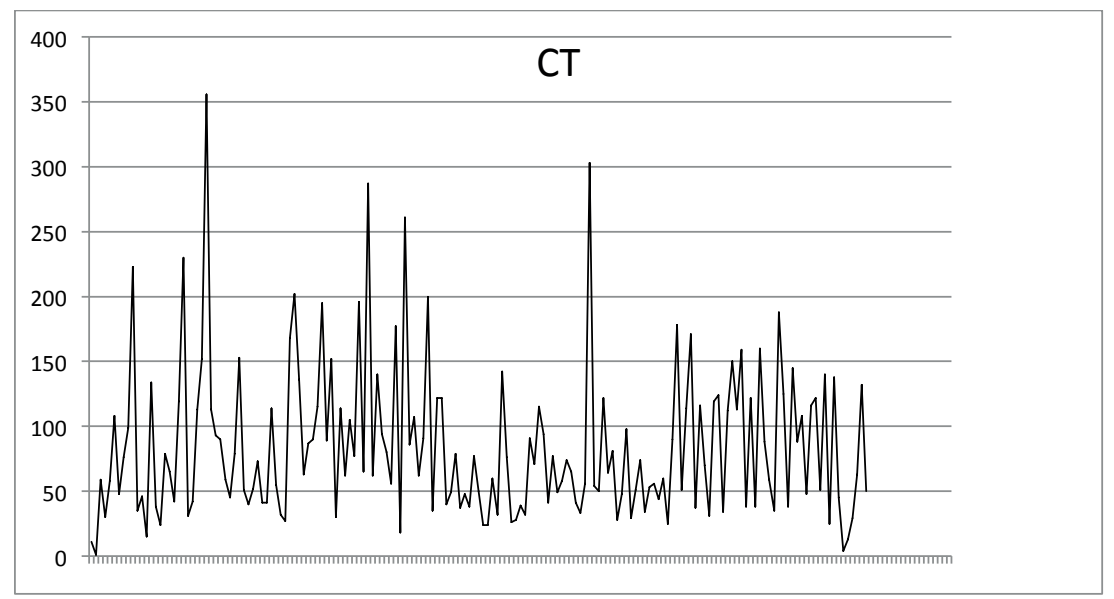

Graf 10: Délka a počet segmentů CT: Waiting for the Dark, Waiting for the Light („Chapter One, $1^{“)}$ Pozn vertikální osa $=$ počet znaků $\mathrm{v}$ segmentu; horizontální osa $=$ počet segmentů $\mathrm{v}$ daném textovém vzorku; barvy: černá $=\mathrm{CT}$

Tabulka 5: Délky a počty segmentů ve VT a CT: Čekání na tmu, čekání na světlo / Waiting for the Dark, Waiting for the Light („Kapitola první, 1.“ / „Chapter One, 1“)

\begin{tabular}{|c|c|c|c|c|c|c|}
\hline \multirow{2}{*}{$\begin{array}{l}\text { Počet znaků } \\
\text { v segmentu }\end{array}$} & \multicolumn{3}{|l|}{ VT } & \multicolumn{3}{|l|}{ CT } \\
\hline & $\begin{array}{l}\text { Počet těchto } \\
\text { segm. }\end{array}$ & \multicolumn{2}{|c|}{$\begin{array}{l}\text { Procento těchto } \\
\text { segmentů }\end{array}$} & $\begin{array}{l}\text { Počet těchto } \\
\text { segm. }\end{array}$ & \multicolumn{2}{|c|}{$\begin{array}{l}\text { Procento těchto } \\
\text { segmentů }\end{array}$} \\
\hline $1-30$ & 35 & \multicolumn{2}{|l|}{23,5} & 19 & \multicolumn{2}{|l|}{11,2} \\
\hline $31-50$ & 28 & 18,8 & \multirow[t]{3}{*}{71,1} & 40 & 23,6 & \multirow[t]{3}{*}{84,6} \\
\hline $51-100$ & 44 & 29,5 & & 57 & 33,7 & \\
\hline $101-200$ & 34 & 22,8 & & 46 & 27,2 & \\
\hline $201-250$ & 6 & 4,0 & \multirow[t]{3}{*}{5,4} & 3 & 1,8 & \multirow[t]{3}{*}{4,1} \\
\hline $251-300$ & 0 & 0 & & 2 & 1,2 & \\
\hline $\operatorname{nad} 301$ & 2 & 1,3 & & 2 & 1,2 & \\
\hline celkem & 149 & & & 169 & & \\
\hline
\end{tabular}

\section{Závěry}

Výzkum potvrdil, že popisovaná metoda je dobře využitelná pro analyzování způsobu, jakým překladatelé reagují na délku vět VT, což je jeden ze stylistických rysů každého literárního textu a v některých případech může být výrazným rysem autorského stylu. Stejně dobře je využitelná pro odhalování idiosynkratického stylu překladatele. Provedené analýzy ukazují, že se nemusí jednat o zjištění typu „překladatel A téměř nemění délku vět VT, zatímco překladatel B věty VT výrazně zkracuje“, ale o odhalování tendencí, které 
překladatelé při převodu délky vět uplatňují (např. „zásahy překladatele A se pohybují v rozmezí minimální až střední, zásahy překladatele $\mathrm{B}$ od malých přes střední až po extrémní). Metoda přináší zajímavé výsledky i při zkoumání jediného překladu. Analýza převodu délky vět ve Wilsonově překladu Klímova textu dokládá, že za strategií převodu tohoto stylistického rysu je promyšlená koncepce, jejímž cílem je vytvoření stylisticky sice nivelizovaného, ale cílovému čtenáři přístupnějšího CT. Další analýzy (kvantitativní i kvalitativní), které již nejsou tématem této studie, prokázaly, že tato koncepce zahrnuje i další stylistické rysy Klímova textu a že zpřístupnění textu cílovému čtenáři je jejich společným jmenovatelem a cílem, který překladatelská koncepce sleduje. ${ }^{5}$

Pokud jde o efektivitu metody, jsme přesvědčeni, že její časová náročnost je více než vyvážena množstvím a relevantností dat, která poskytuje. Jak už bylo naznačeno v úvodu, využití elektronických nástrojů na sebe navazuje, což efektivitu metody značně zvyšuje - překladové paměti vytvořené v některém z CAT nástrojů se dají použít jako vstup do korpusových manažerů, schopných vytvořit paralelní tagované korpusy konkrétních textů/překladatelů/autorů. Dalším krokem pak může být vytvoření korpusu s manuální víceúrovňovou anotací, např. v nástroji Graph Anno, který umožňuje tagovat texty podle parametrů, na které je analýza zaměřena. Způsoby použití tagovaných/manuálně tagovaných korpusů pro analyzování stylu a jeho převodu v překladu jsou tématem dalšího výzkumu.

\section{BIBLIOGRAFIE}

\section{Primární zdroje}

Holub, Miroslav (1987) K principu rolničky, Praha: Melantrich.

(1992) The Jingle Bell Principle, překlad James Naughton, Newcastle upon Tyne: Bloodaxe Books. Hrabal, Bohumil (1971) Obsluhoval jsem anglického krále: Povídky, Praha: Jazzová sekce.

(1976) Postřižiny, Praha: Československý spisovatel.

(1991) Městečko, kde se zastavil čas, Praha: Odeon.

(1993) The Little Town Where Time Stood Still and Cutting It Short, překlad James Naughton, New

York: Pantheon Books.

(2003) Inzerát na dům, ve kterém už nechci bydlet, Praha: Mladá fronta.

(2007) I Served the King of England, překlad Paul Wilson, New York: New Directions.

(2015) Mr. Kafka and Other Tales from the Times of the Cult, překlad Paul Wilson, New York: New Directions.

Klíma, Ivan (1995) Waiting for the Dark, Waiting for the Light, překlad Paul Wilson, New York: Grove Press.

(1996) Čekání na tmu, čekání na světlo, Praha: Hynek.

\section{Sekundární zdroje}

Baker, Mona (1993) 'Corpus Linguistics and Translation Studies: Implications and Applications', in Mona Baker, Gill Francis and Elena Tognini-Bonelli (eds.) Text and Technology: In Honor of John Sinclair, Amsterdam: John Benjamins, 233-50.

(2000) 'Towards a Methodology for Investigating the Style of a Literary Translator', Target 12(2): 241-66.

5 „Z názoru na dílo a ze zaměření na konzumenta určitého typu vyrůstá překladatelovo pojetí předlohy, překladatelská koncepce“ (Levý 1998: 64). 
Boase-Beier, Jean (2006) Stylistic Approaches to Translation, Manchester: St. Jerome.

Bosseaux, Charlotte (2007) How Does It Feel? Point of View in Translation: The Case of Virginia Woolf into French, Amsterdam: Rodopi.

Kenny, Dorothy (2001) Lexis and Creativity in Translation: A Corpus-Based Study, Manchester: St. Jerome.

Laviosa, Sara (1998) ‘The Corpus-Based Approach: A New Paradigm in Translation Studies', Meta 43(4): $1-6$.

Levý, Jiří (1998) Umění prekladu, Praha: Ivo Železný.

Malmkjær, Kirsten (2003) 'What Happened to God and the Angels: An Exercise in Translational Stylistics', Target 15(1): 37-58.

Munday, Jeremy (2016) Introducing Translation Studies: Theories and Applications, 4th ed., New York: Routledge.

Partridge, James (2000) 'Bohumil Hrabal', in Olive Classe (ed.) Encyclopedia of Literary Translation into English: Vol. 1, Londýn: Fitzroy Dearborn Publishers, 667-70.

Saldanha, Gabriela (2011) 'Translator Style: Methodological Considerations', The Translator 17(1): 25-50.

Saldanha, Gabriela a Sharon O’Brien (2014) Research Methodologies in Translation Studies, New York: Routledge.

Snell-Hornby, Mary (1988) Translation Studies: An Integrated Approach, Amsterodam: John Benjamins.

Zehnalová, Jitka (2016) 'Literary Style and Its Transfer in Translation: Bohumil Hrabal in English', in The Art of Translation: Jiři Levý (1926-1967) y la otra historia de la Traductología, Mutatis Mutandis 9(2): 418-44.

\section{Online zdroje}

Graph Anno, https://github.com/LBierkandt/graph-anno (access: 1. 10. 2016).

Memsource Cloud, https://cloud.memsource.com/web/login/auth?backUrl=\%2Fhome (access: 1. 10. 2016).

Sketch Engine, https://www.sketchengine.co.uk/ (access: 1. 10. 2016).

\section{RESUMÉ}

Die Übersetzung des Stils in der literarischen Übersetzung: Verwendung von CAT-Instrumenten und Parallelkorpora

Unser Beitrag befasst sich mit der Verwendung von elektronischen Instrumenten in Bezug auf die Untersuchung des Autorenstils in der literarischen Übersetzung. Die Autorin des Beitrags stellt die Methode der Satzlängeanalyse in den Ausgangs- (weiter als AT) und Zieltexten (weiter als ZT) vor, zuerst mittels von Excel-Graphiken und weiter mittels von dem im CAT-MemsourceCloud erschaffenen „Übersetzungsgedächtnis“ (Translation Memory, weiter als TM). Die Möglichkeiten dieser Methode werden anhand von Beispielen aus Hrabals Texten demonstriert: Die Schur und Ich habe den englischen König bedient, in englischer Übersetzung von James Naughton und Paul Wilson. Weiter wird die Methode in Bezug auf die Untersuchung des Autorenstils anhand weiterer Texte Hrabals verifiziert: Das Städtchen, in dem die Zeit stehen blieb und Verkaufe Haus, in dem ich nicht mehr wohnen will. Des Weiteren dienen zur Verifizierung auch Werke anderer tschechischer Autoren, die von denselben Translatoren ins Englische übersetzt wurden (so etwa Holubs Text Zum Prinzip der Schelle in Naughtons Translation und Klímas Warten auf Dunkelheit, Warten auf Licht in Wilsons Übersetzung).

Des Weiteren werden quantitative Daten zu diesen Texten tabellarisch zusammengefasst und es wird gezeigt, wie sie interpretiert werden können und für die vergleichende stilistische Analyse der AT/ZT und die Beschreibung der Translationsstrategien anzuwenden sind. Die Autorin kommt zum Schluss, dass die beschriebenen Anwendungsmethoden der elektronischen Instrumente gut anwendbar sind für die Behandlung der Autorenstilübersetzung und des Autorenstils in der Übersetzung. Die in Anspruch genommene Zeit wird durch umfangreiche und relevante Resultate mehr als kompensiert. Die Effektivität wird noch wesentlich dadurch erhöht, wenn TM als eine gewisse Vorstufe für das Erschaffen kleiner 
Korpora verwendet werden, d.h. als in Korpusmanager wie etwa Sketch Engine importierte Dateien, die im Stande sind, getagte Parallelkorpora konkreter Texte/Übersetzer/AutorInnen zu erschaffen, oder auch ein Korpus mit manueller Multi-Level- Annotation etwa im Tool GraphAnno.

Mgr. Jitka Zehnalová, Dr.

Katedra anglistiky a amerikanistiky, Filozofická fakulta Univerzity Palackého, Olomouc jitka.zehnalova@upol.cz

This study has been supported by Grant of the Czech Ministry of Education, Youth and Sports No. IGA_FF_2018_012 (Internationalization of Anglo-American Literary Science, English Linguistics and Translation Studies).

Př́spěvek vznikl za podpory MŠMT, grant IGA_FF_2018_012 (Internacionalizace v oblasti angloamerické literární vědy, lingvistiky a translatologie). 